\title{
PENERAPAN BERPIKIR KRITIS OLEH PERAWAT DALAM \\ BERKOLABORASI DENGAN DOKTER
}

\author{
SRI HARVITA SARI MARPAUNG/181101125
}

\author{
Sriharvitaaasm11@gmail.com
}

\begin{abstract}
ABSTRAK
Dalam dunia kesehatan tentu akan ada kolaborasi antar sesama profesi kesehatan yang salah satunya adalah dokter dengan perawat. Dalam kolaborasi ini perawat dituntut harus memiliki kemampuan berpikir kritis sehingga dapat meningkatkan kualitas layanan kesehatan, dalam kolaborasi ini perawat dengan dokter diharuskan memiliki kerjasama, komunikasi yang baik, dan dapat melaksanakan kewajibannya masing - masing serta mampu saling menghargai dan memiliki rasa percaya satu sama lain sehingga dalam proses keperawatan pasien dapat menerima yang terbaik. Oleh karena itu berpikir kritis merupakan satu elemen penting bagi seorang perawat saat melakukan pengambilan keputusan.
\end{abstract}

Kata kunci : berpikir kritis, perawat, kolaborasi, dokter

\begin{abstract}
In the world of health, of course there will be collaboration between Health professions, one of which is a doctor and a nurse. In this collaboration, nurse are required to have critical support, can improve the quality of health services, in this collaboration nurses with doctors are required to have cooperation, good communication, and can support each other and increase trust. In the nursing process the patient can receive the best. Therefore critical thingking is an important element for nurses when making decisions.
\end{abstract}

Keywords : critical thingking, nurses, collaboration, doctors.

\section{LATAR BELAKANG}

Secara defenisi berpikir kritis merupakan aktivitas yang dilakukan secara berkesinambungan yang bertujuan untuk mencapai sesuatu dengan maksimal. Dalam berbagai profesi berpikir kritis merupakan hal yang sangat penting dalam mencapai keprofesionalan dan juga untuk mencapai hasil yang maksimal dalam tiap - tiap pekerjaan yang ditekuni.
Salah satunya adalah profesi keperawatan, dalam dunia keperawatan berpikir kritis merupakan hal yang harus dimiliki oleh seorang perawat sehingga dalam melakukan tindakan ataupun pengambilan keputusan untuk memberikan asuhan keperawatan perawat mampu memperhitungkan setiap masalah dan solusi yang dapat digunakan untuk mengatasi masalah tersebut serta dapat memperhitungkan 
dampak dari tindakan tersebut untuk pasien maupun perawat.

Dalam dunia kesehatan standar yang harus dicapai yang paling utama adalah pemenuhan hak - hak pasien dalam pemberian layanan kesehatan, oleh sebab itu semua pelayan kesehatan di dalam rumah sakit harus mampu memberikan pelayanan yang terbaik untuk mewujudkan hak - hak pasien yaitu meningkatkan kesehatan pasien. Seperti yang telah kita ketahui, perawat merupakan salah satu tenaga medis yang paling dekat dengan pasien maka seorang perawat harus mampu untuk mengetahui apa saja yang dibutuhkan oleh pasien dan disinilah seorang perwat harus memiliki kemampuan berpikir kritis dalam pengambilan keputusan untuk tindakan yang akan dilakukan.

Dalam menjalankan kewajibannya perawat tentu tidak dapat bekerja sendiri, perawat harus bisa berkolaborasi dengan tim medis lainnya salah satunya adalah dokter, tujuan dari kolaborasi ini yaitu untuk membantu menyelesaikan ataupun memecahkan masalah pasien. Dalam kolaborasi ini perawat tentunya harus bisa berpikir kritis sehingga dalam pengambilan keputusan untuk perawatan pasien perawat dapat berperan dan bisa bekerjasama dengan maksimal untuk peningkatan kesehatan pasien.

\section{TUJUAN}

Tujuan dari penulisan ini adalah untuk mengetahui lebih banyak lagi tentang apa saja peranan seorang perawat dalam berkolaborasi dengan dokter dengan cara berpikir kritis.

\section{METODE}

Metode yang digunakan dalam penulisan ini menggunakan literature riview berdasarkan teks book, jurnal, ebook (10 tahun terakhir) dengan cara menganalisis, eksplorasi sumber dan kajian bebas.

\section{HASIL}

Hasil yang akan didapatkan dari penulisan ini adalah peran tentang kemampuan berpikir kritis yang dimiliki oleh seorang perawat saat berkolaborasi dengan dokter dan cara penanganan perawat dalam membantu memecahkan masalah ketika dihadapkan dalam satu kondisi untuk mencapai tujuan yaitu kualitas proses keperawatan yang ditujukan kepada pasien. 


\section{PEMBAHASAN}

Dalam dunia kesehatan kata kolaborasi bukanlah satu hal yang jarang lagi karena setiap pelayan kesehatan di rumah sakit saling membutuhkan sehingga dalam melaksanakan layanan kesehatan semua pelayan kesehatan termasuk hubungan kolaborasi antara perawat dan dokter harus bisa berkolaborasi atau yang sering kita sebut dengan bekerja sama dengan baik untuk tujuan peningkatan kesehatan pasien/klien. Dalam berkolaborasi perawat dan dokter harus bisa mencapai kriteria bekerjasama yang baik yaitu kerjasama (cooperation), tanggung jawab (coordination), komunikasi (communicatin), saling menghormati dan percaya (mutual respect). Dalam pelaksanaan kolaborasi ini perawat dan dokter harus saling memberi pertimbangan/pandangan, mengoreksi bila ada yang salah atau kurang tepat, tidak memaksakan kehendak/dapat mengubah pandangan serta perspektif pribadi, serta melengkapi satu sama lain karena perawat dan dokter adalah mitra dalam dunia kesehatan.

Dalam pelaksanaan kerjasama perawat harus mampu berpikir kritis mengenai apa yang harus dilakukan oleh perawat dalam mewujudkan kerjasama yang baik, dalam hal ini seorang perawat harus memiliki kemampuan yang baik sehingga saat bekerjasama dengan dokter perawat mampu mengemukakan pendapatnya sehingga perawat tidak didominasi oleh dokter. Begitu juga sebaliknya dokter harus mampu bekerjasama dengan perawat secara profesional.

Dalam pelaksanaan tanggung jawab perawat harus mampu melaksanakan tanggungjawab yang diberikan oleh dokter dengan baik, perawat harus bisa berpikir kritis bagaimana dia bisa menyelesaikan tugasnya dengan maksimal. Seperti dalam melaksanakan kewajibannya perawat harus memiliki inisiatif sendiri untuk melakukan suatu tindakan kepada pasien bila pasien tersebut membutuhkan penanganan tanpa harus menunggu perintah dari dokter namun dengan prinsip perawat harus tetap dapat mempertimbangkan tentang tindakan yang akan dilakukan kepada pasien apakah tindakan tersebut bermanfaat atau justru merugikan si pasien bahkan juga perawat dan tim medis lainnya.

Dalam pelaksanaan komunikasi seperti yang telah kita ketahui bahwa 
komunikasi merupakan hal yang intim bagi setiap orang begitu juga dengan perawat. Dalam berkolaborasi perawat harus memiliki kemampuan berkomunikasi yang baik dan benar dan seorang perawat dapat memiliki komunikasi yang baik apabila perawat tersebut mampu berpikir kritis sehingga apa yang akan disampaikan oleh dokter maupun sebaliknya kedua belah pihak tidak mendapatkan informasi yang salah. Misalnya dalam pemeriksaan pasien seorang perawat setelah melakukan pemeriksaan atau tindakan maka perawat akan mendokumentasikan hasil dari pemeriksaan tersebut dan hasil tersebut akan disampaikan kepada dokter yang menangani pasien tersebut dengan komunikasi yang baik sehingga dalam pemberian perawatan akan lebih mudah.

Dalam pelaksanaan saling menghormati dan percaya hal ini merupakan hal yang penting karena dalam berkolaborasi rasa saling menghormati dan percaya sangat dibutuhkan, tanpa rasa saling menghormati dan percaya hubungan kolaborasi antara perawat dengan dokter akan canggung. Hal ini dapat kita lihat bila salah satunya tidak menghargai keputusan yang lain maka akan timbul rasa ketidakpercayaan. Perawat dalam hal ini dituntut harus mampu menghormati dan memiliki rasa percaya terhadap dokter, namun bukan berarti semua yang dilakukan oleh dokter sepenuhnya harus kita lakukan dalam situasi inilah seorang perawat dapat berpikir kritis agar dapat membedakan mana yang layak dilakukan tanpa harus menyinggung perasaan si dokter dan tetap menjalin rasa kepercayaan karena elemen saling menghormati dan percaya mempengaruhi keberhasilan kolaborasi.

\section{PENUTUP}

Dalam berkolaborasi dengan dokter perawat harus memiliki kemampuan untuk berpikir kritis saat dihadapkan pada suatu situasi yang benar - benar membutuhkan keputusan untuk mencapai tujuan yaitu peningkatan kesehatan pasien.

\section{REFERENSI}

Deswani (2009), Proses Keperawatan dan Berpikir Kritis. Salemba : Jakarta

Deniati Kiki, dkk (2016), Gambaran Kemampuan Berpikir Kritis Perawat Primer dalam Pelaksanaan Asuhan Keperawatan di Rumah Sakit Islam Surakarta Jurnal Kesehatan Holistik (The Journal of Holistic Healthcare), Volume 12, No. 1, Januari 2018 : 21 25 
Fatih, A., \& Simamora, R. H. (2019, March). Investigating nurses' coping strategies in their workplace as an indicator of quality of nurses' life In Indonesia : a preminary study. In $I O P$ Conference Series : Earth and Environmental Science (Vol. 248, No. 1, p. 012031). IOP Publishing.

Karen. 1992. Fundamentals of Nursing : Collaborating for Optimal Health.

East Norwalk : Appleton \& Lange

Simon \& Schuster Business and Professional Group.

Mulyaningsih. 2013. Peningkatan Perilaku Caring Melalui Kemampua Berpikir Kritis Perawat. Jurnal Keperawatan. 1 (2) : $100-6$

Potter \& Perry. 2005. Buku Ajar Fundamental Keperawatan : Konsep, proses dan praktik. Edisi 4. Jakarta : EGC.

Potter \& Perry. 2010. Fundamental of Nursing (fundamental Keperawatan). Buku 1. Edisi 7. Indonesia : Salemba Medika.

Potter \& Perry. 2010. Fundamental of Nursing (fundamental Keperawatan). Buku 2. Edisi 7. Indonesia : Salemba Medika.

Potter \& Perry. 2010. Fundamental of Nursing (fundamental Keperawatan).
Buku 3. Edisi 7. Indonesia : Salemba Medika.

Ramadhiani, R. O., \& Siregar, T. 2019. Hubungan Berpikir Kritis dengan Kepedulian (Caring) Perawat dalam Melaksanakan Asuhan Keperawatan di RSUD Kota Depok Jurnal Kesehatan Kedokteran, 15, (2) : 149 - 150

Robinson F. Patrick, Gorman G., Lynda W. Simmer and Rachel Yudkowky. Communication in hospitals. Nursing Forum, 45, 3.

Rubenfeld, M. G., scheffer,B. K. 2007. Berpikir Kritis dalam Keperawatan. Jakarta : EGC.

Syah, Candra (2017). Buku Ajar Manajemen Keperawatan : Teori dan Aplikasi Praktek Dilengkapi dengan Kuisioner Pengkajian Praktek Manajemen Keperawatan. Bogor : IN MEDIA

Sumijatun. 2009. Manajemen

Keperawatan Konsep Dasar dan Aplikasi Pengambilan Keputuan Klinis. Jakarta : TIM

Terry, Cynthia Lee. 2011. Keperawatan Kritis. Yogyakarta : Rapha Publishing. 